\title{
High efficiency of energy utilization in 'cafeteria'- and force-fed rats kept at $29^{\circ}$
}

\author{
BY H. GILLIAN BARR \\ Department of Agricultural and Food Chemistry, The Queen's University of Belfast, \\ Newforge Lane, Belfast BT9 5PX \\ AND K. J. MCCRACKEN \\ Agricultural and Food Chemistry Research Division, Department of Agriculture, Northern \\ Ireland and The Queen's University of Belfast, Newforge Lane, Belfast BT9 5PX
}

\section{(Received 18 March 1983 - Accepted 29 November 1983)}

1. Male, Sprague-Dawley (Charles-River) rats, of initial weight $272 \mathrm{~g}$, were given a powdered stock diet (T1) ad lib., force-fed a synthetic diet (T2) or offered a range of palatable foods in conjunction with the powdered stock diet (T3) or a similar diet supplemented with certain minerals and vitamins (T4).

2. Metabolizable energy (ME) intake (kJ/d) averaged 303, 453, 402 and 383 for T1, T2, T3 and T4 respectively and corresponding weight gains were $5 \cdot 5,6 \cdot 9,8.2$ and $7.9 \mathrm{~g} / \mathrm{d}$ and were significantly different $(P<0 \cdot 001)$.

3. The intakes of $\mathrm{T} 3$ and $\mathrm{T} 4$ rats ranged from 10 to $60 \%$ above the mean value for $\mathrm{T} 1$.

4. Crude protein $(\mathrm{CP}$; nitrogen $\times 6.25$ ) retentions were similar for $\mathrm{T} 1$, $\mathrm{T} 3$ and $\mathrm{T} 4$ rats and significantly lower $(P<0.01)$ for T2 rats. Fat retentions were $1 \cdot 1,4 \cdot 1,2.9$ and $2.4 \mathrm{~g} / \mathrm{d}$ for T1 to T4 respectively $(P<0.001)$.

5. The energy contents of the gain $(\mathrm{MJ} / \mathrm{kg})$ were $12 \cdot 7,26 \cdot 0,16 \cdot 7$ and $14 \cdot 9$ for T1 to T4 respectively $(P<0 \cdot 001)$ and energy retentions $(\mathrm{kJ} / \mathrm{d})$ were $70,179,139$ and 117 respectively $(P<0.001)$.

6. A linear regression of energy retention (ER) on $\mathrm{ME}$ yielded a slope of 0.78 and a mean energy requirement for zero balance of $510 \mathrm{~kJ} / \mathrm{kg}$ body-weight $\mathrm{t}^{-75}$.

7. These results are in conflict with reports of 'diet-induced thermogenesis' in 'cafeteria '-fed rats.

The laboratory rat has been used extensively as an experimental model of obesity in man. Hyperphagia can be achieved by feeding high-fat diets (Mickelsen et al. 1955) by gastric intubation (Cohn \& Joseph, 1959) or by offering a varied diet (Scalafani \& Springer, 1976). With the former two methods the efficiency of energy utilization is consistently high (Schemmel et al. 1972; McCracken \& McNiven, 1983). However, Rothwell \& Stock (1979) reported that 'cafeteria'-fed rats, i.e. those offered a varied diet, consumed more than twice as much energy as control rats given a pelleted stock diet but that most of the extra energy consumed was liberated as heat. This phenomenon, designated 'diet-induced thermogenesis', has since been reported in various strains of rats (Rothwell \& Stock, 1982) and in mice (Trayhurn et al. 1982) although Armitage et al. (1981) did not observe any significant alteration in the efficiency of utilization of energy by 'cafeteria'-fed rats. Most studies have been conducted at $24^{\circ}$, i.e. below the zone of thermoneutrality (Swift, 1944) but Andrews \& Donne (1982) reported a large increase in the oxygen consumption of 'cafeteria'-fed rats at $30^{\circ}$.

One difficulty with 'cafeteria'-feeding is that many of the palatable foods used are poor sources of minerals and vitamins, and it seemed probable that the varied diet was deficient in some important nutrients. On the other hand, the fat content of a varied diet is much higher than that of the stock diet with which it has been compared in previous studies.

The aims of the present experiment were: (1) to determine the effect of 'cafeteria'-feeding on energy intake and expenditure of rats in a thermoneutral environment, (2) to compare the efficiency of energy utilization of rats given a varied diet or force-fed a synthetic diet of equivalent nutrient content and (3) to determine the effect on energy utilization of improving the nutrient balance of the varied diet. 


\section{EXPERIMENTAL}

Thirty male, Sprague-Dawley rats, obtained from Charles-River, Kent, were acclimatized to their new environment for at least 1 week prior to the start of the experiment. They were weighed daily and, on the 7th day, allocated to one of six weight blocks (five rats per block). When a block reached the mean initial weight of $272 \mathrm{~g}$, each rat was randomly allocated to one of four dietary regimens (Table 1) or slaughtered for initial carcass composition. All animals were housed individually in wire metabolism cages. Room temperature was $29 \pm 1^{\circ}$ and the light-dark cycle was: light, $08.00-18.00$ and $20.00-22.00$ hours; dark, $18.00-20.00$ and $22.00-08.00$ hours. This arrangement was to facilitate tube-feeding. The cages for $\mathrm{T} 1$ and $\mathrm{T} 2$ rats were placed over plastic containers charged with $0 \cdot 11$ sulphuric acid $(0 \cdot 1 \mathrm{M})$. Faeces and urine were collected together for $7-\mathrm{d}$ periods and subsequently freeze-dried. The cages for T3 and T4 rats were placed over solid trays lined with absorbent paper to facilitate separation of feed and faeces.

The rats were weighed daily and approximate daily intakes of individual feeds were determined so that the nutrient intakes could be estimated. After $21 \mathrm{~d}$ the rats were killed by chloroform anaesthesia, undigested food residues were removed from the gastrointestinal tract and various organs, including liver, interscapular brown adipose tissue (IBAT), epididymal and kidney fat pads, were removed and weighed. The livers were stored separately at $-20^{\circ}$ for subsequent analysis. The carcasses were prepared for analysis as described by McCracken \& McNiven (1983). Samples of milled freeze-dried material were analysed for crude protein (CP; nitrogen $\times 6.25)$ by the macro-Kjeldahl method, for ash by ignition in a muffle furnace at $500^{\circ}$ for $8 \mathrm{~h}$ and for ether extract by the Soxhlet method (40-60 $0^{\circ} \mathrm{BP}$; petroleum ether). Carcass energy retention (ER) was calculated from protein and fat retention using the factors 23.8 and $39.3 \mathrm{MJ} / \mathrm{kg}$ respectively (Brouwer, 1965). The livers were analysed by the same method after freeze-drying and milling. Glycogen was calculated by difference.

\section{Diets}

The compositions of the three synthetic diets are shown in Table 2. The palatable foods used to form the varied diet were:

$\begin{array}{lll}\text { Bacon } & \text { Cream crackers } & \text { Battenburg cake } \\ \text { Corned beef } & \text { Hovis crackers } & \text { Swiss roll } \\ \text { Luncheon meat } & \text { Digestive biscuits } & \text { Sponge cake } \\ \text { Breakfast strips } & \text { Rich-tea biscuits } & \text { Fairy cake } \\ \text { Pork sausage } & \text { Ginger-thins } & \text { Ginger cake } \\ \text { Beef sausage } & \text { Shortbread } & \text { Sponge fingers } \\ \text { Chopped ham \& pork } & \text { Cracottes } & \text { Popcorn } \\ \text { Cheese } & \text { Milk chocolate } & \text { Cheese wotsits } \\ \text { Crisps } & \text { Milky Way } & \text { Pasta }\end{array}$

Some of these were found not to be accepted by the rats and were offered only once. Four foods were offered daily, two at 09.30 hours and two at 20.30 hours. A meat course was offered each evening and a regimen as similar as possible to that of Rothwell \& Stock (1979) was followed. The food given to the force-fed animals was mixed to a slurry with tepid water immediately prior to administration. At each feeding time, representative samples were taken for dry matter (DM) determinations $\left(100^{\circ}\right.$ in a forced-draught oven for $\left.24 \mathrm{~h}\right)$. Initially the tube-fed animals were given $6 \mathrm{ml}$, containing approximately $0.75 \mathrm{~g} \mathrm{DM} / \mathrm{ml}$, three times daily at $09.00,16.00$ and 21.00 hours. This was increased to $30 \mathrm{ml} / \mathrm{d}$ over the first week. 
Table 1. Experimental treatments

\begin{tabular}{ccl}
\hline Treatment & Diet & \multicolumn{1}{c}{ Dietary regimen } \\
\hline T1 & 1 & Powdered stock diet $a d$ lib. \\
T2 & 2 & Force-fed, three times daily \\
T3 & 1 & Powdered stock plus four palatable foods daily \\
T4 & 3 & Powdered stock plus four palatable foods daily \\
T5 & - & Starting controls \\
\hline
\end{tabular}

Table 2. Composition and analysis of synthetic diets $(\mathrm{g} / \mathrm{kg})$ given alone or in combination with palatable foods*

\begin{tabular}{lccc}
\hline \hline Diet... & 1 & 2 & 3 \\
\hline Casein & 180 & 180 & 180 \\
Sucrose & 250 & 250 & 250 \\
Starch & 480 & 428 & 467 \\
Maize oil & 30 & 100 & 30 \\
Dunn's salt $\dagger$ & 50 & 35 & 50 \\
Vitamin mixture $\ddagger$ & 10 & 7 & 20 \\
Methionine & - & -170 & 3 \\
Crude protein (nitrogen $\times 6 \cdot 25)(\mathrm{g} / \mathrm{kg} \mathrm{DM})$ & 163 & $19 \cdot 9$ & 163 \\
Gross energy $(\mathrm{MJ} / \mathrm{kg} \mathrm{DM})$ & $18 \cdot 1$ & $19 \cdot 3$ & $17 \cdot 3$ \\
Metabolizable energy $(\mathrm{MJ} / \mathrm{kg} \mathrm{DM})$ & $17 \cdot 2$ & & \\
\hline \hline
\end{tabular}

* See Table 1.

† Contained $(\mathrm{g} / \mathrm{kg})$ : calcium orthophosphate 434.0 , potassium chloride $271 \cdot 0$, disodium hydrogen phosphate $114 \cdot 2$, magnesium sulphate $87 \cdot 0$, sodium chloride $54 \cdot 5$, ferric citrate $38 \cdot 0$, calcium iodide $1 \cdot 1$, manganese sulphate 0.20 , sodium fluoride 0.01 .

$\ddagger$ Contained $(\mathrm{g} / \mathrm{kg})$ : retinol 3.44, cholecalciferol 0.05, $\alpha$-tocopheryl acetate 10, choline 100, inositol 10 , $p$-aminobenzoic acid 5 , niacin 4 , menadione 1 , pyridoxine $0 \cdot 50$, thiamin $0 \cdot 50$, riboflavin $0 \cdot 32$, folic acid $0 \cdot 10$, biotin 0.02 , cyanocobalamin 0.002 .

$\S$ Determined directly for diets 1 and 2 and calculated as 0.96 digestible energy for diet 3.

\section{Calculation of nutrient composition of varied diets}

Palatable foods were weighed individually and refusals and spillage separated daily and weighed so that the consumption of each item could be estimated. Refusals of meats and foods of low DM content were dried at $100^{\circ}$ for $24 \mathrm{~h}$ before conversion of refused food back to a fresh matter basis. Each food was analysed for DM content and gross energy (GE). Diets 1 and 3 were weighed daily and replenished when necessary.

The vitamin contents of the synthetic diets were calculated from the dietary ingredients. Proximate constituents, energy and minerals were determined. The nutrient composition of the total diet consumed by each T3 and T4 rat was calculated from the weights of the individual food items consumed, DM and energy values obtained by direct analysis and values for other nutrients taken from food tables (Paul \& Southgate, 1978).

\section{Measurement of energy balance}

At the end of the experiment, the three weekly samples of freeze-dried excreta for each rat in $\mathrm{T} 1$ and $\mathrm{T} 2$ were bulked and energy determined by adiabatic bomb calorimetry. The metabolizable energy (ME) intake was determined by subtraction of the excreta energy from the GE consumed. For T3 and T4 the GE offered was calculated from the total weight of each food item and its measured GE content. The digested energy (DE) consumed was 
Table 3. Metabolizable energy $(M E)$ intake $(k J / d)$, gains of weight, crude protein $(C P$; nitrogen $\times 6.25)$, fat $(\mathrm{g} / \mathrm{d})$ and energy $(\mathrm{kJ} / \mathrm{d})$ and energy content of gain $(\mathrm{MJ} / \mathrm{kg})$ and gross efficiency for rats given diet 1 ad lib. (T1), force-fed diet $2(T 2)$ or offered a varied diet in combination with diet 1 (T3) or diet 3 (T4) for 21 d†

(Mean values and standard error of the difference for six rats, $13 \mathrm{df}$ )

\begin{tabular}{|c|c|c|c|c|c|c|}
\hline Treatment... & T1 & $\mathrm{T} 2$ & T3 & T4 & SED & $\begin{array}{l}\text { Statistical } \\
\text { significance }\end{array}$ \\
\hline ME intake $(\mathrm{kJ} / \mathrm{d})$ & 303 & 453 & 402 & 383 & $21 \cdot 8$ & $* * *$ \\
\hline Wt gain $(\mathrm{g} / \mathrm{d})$ & $5 \cdot 5$ & $6 \cdot 9$ & $8 \cdot 2$ & $7 \cdot 9$ & 0.65 & $* *$ \\
\hline $\mathrm{CP}$ gain $(\mathrm{g} / \mathrm{d})$ & $1 \cdot 04$ & 0.65 & $1 \cdot 11$ & $1 \cdot 14$ & $0 \cdot 106$ & $* *$ \\
\hline Fat gain $(g / d)$ & $1 \cdot 12$ & 4.09 & $2 \cdot 86$ & $2 \cdot 43$ & 0.411 & $* * *$ \\
\hline Energy gain $(\mathrm{kJ} / \mathrm{d})$ & 70 & 178 & 139 & 117 & $11 \cdot 71$ & $* * *$ \\
\hline $\begin{array}{l}\text { Energy content } \\
\text { of gain }(\mathrm{MJ} / \mathrm{kg})\end{array}$ & $12 \cdot 7$ & $26 \cdot 0$ & $16 \cdot 7$ & 14.9 & 1.46 & $* * *$ \\
\hline $\begin{array}{l}\text { Gross efficiency of } \\
\text { energy gain }\end{array}$ & $0 \cdot 23$ & $0 \cdot 39$ & 0.34 & $0 \cdot 31$ & $0 \cdot 019$ & $* * *$ \\
\hline
\end{tabular}

$* * P<0.01, * * * P<0.001$.

+ For details of diets and treatments, see Tables 1 and 2.

obtained by subtracting the energy content of the combined food refusals, spilt food and faeces for the 21-d period from the GE offered. ME was estimated as 0.96 DE (Agricultural Research Council, 1981). Heat production was calculated as the difference between ME intake and ER.

The results were subjected to analysis of variance, an iterative procedure being used to estimate missing plots which occurred due to the premature deaths of two T2 rats.

\section{RESULTS}

The ME intake of the rats offered a varied diet (T3 and T4) ranged from 334 to $478 \mathrm{~kJ} / \mathrm{d}$, an increase of between 10 and $60 \%$ over the mean $\mathrm{T} 1$ intake. The mean increases in ME intake for $\mathrm{T} 2, \mathrm{~T} 3$ and $\mathrm{T} 4$ over $\mathrm{T} 1$ were, respectively, 50, 33 and $26 \%$ (Table 3 ) and were significant $(P<0.001)$. Weight gain was lowest for T1 and highest for T3 and T4, the difference being significant $(P<0.01)$. Carcass CP gain was similar for T1, T3 and T4 and significantly lower $(P<0.01)$ for T2. Carcass fat gain was 265,157 and $117 \%$ higher for T2, $\mathrm{T} 3$ and T4 rats respectively than for the controls $(P<0.001)$. As a consequence of the large differences in the proportions of $\mathrm{CP}$ and fat in the carcass gain, there were large differences in the energy content of the gain. The mean energy content of the gain of $\mathrm{T} 2$ rats $(26.0 \mathrm{MJ} / \mathrm{kg})$ was significantly greater $(P<0.001)$ than that of the other three treatments and more than twice that of $\mathrm{T} 1$ rats. Carcass energy gain was significantly increased by giving a varied diet or by force-feeding $(P<0.001)$. Gross efficiency of energy gain was lowest for $\mathrm{T} 1$ and significantly higher for T3 and T4 $(P<0.001)$ and for T2 $(P<0.001)$.

When the results were expressed per unit metabolic body-weight $\left(\mathrm{kg} \mathrm{W}^{0.75}\right)$ the calculated mean heat productions (Table 4 ) of $\mathrm{T} 1, \mathrm{~T} 3$ and $\mathrm{T} 4$ rats were similar and significantly lower $(P<0.05)$ than for T2 rats. Because of the range of ME intake which occurred in T1, T3 and T4, it was possible to plot a regression of ER on ME intake (Fig. 1). The pooled results yielded the equation

$$
\operatorname{ER}\left(\mathrm{kJ} / \mathrm{d} \text { per } \mathrm{kg} \mathrm{W}^{0.75}\right)=0.78 \mathrm{ME}-395(r 0.95) \text {. }
$$

Applying the pooled slope to the individual treatments yielded estimates of the energy requirement for zero balance of 505, 508, 476 and 502 for $\mathrm{T} 1, \mathrm{~T} 2, \mathrm{~T} 3$ and $\mathrm{T} 4$ respectively. 
Table 4. Metabolizable energy (ME) intake, energy retention (ER) and calculated heat production (HP; $\mathrm{kJ} / \mathrm{d}$ per $\mathrm{kg}$ body-weight $t^{0.75}$ ) of rats given diet $\mathrm{l} \mathrm{ad}$ lib. (Tl), force-fed diet $2(T 2)$ or offered a varied diet in combination with diet 1 (T3) or diet $3(T 4)$ for $21 d \dagger$

(Mean values and standard error of the difference for six rats, $13 \mathrm{df}$ )

\begin{tabular}{|c|c|c|c|c|c|c|}
\hline Treatment... & $\mathrm{T} 1$ & $\mathrm{~T} 2$ & $\mathrm{~T} 3$ & $\mathrm{~T} 4$ & SED & $\begin{array}{c}\text { Statistical } \\
\text { significance }\end{array}$ \\
\hline ME intake & 719 & 1030 & 858 & 827 & $34 \cdot 1$ & $* * *$ \\
\hline ER & 165 & 405 & 294 & 252 & $31 \cdot 5$ & $* * *$ \\
\hline HP & 553 & 625 & 564 & 575 & $21 \cdot 3$ & $*$ \\
\hline
\end{tabular}

$* P<0.05,{ }^{* * *} P<0.001$.

$\dagger$ For details of diets and treatments, see Tables 1 and 2.

Table 5. Weight $(\mathrm{g})$ of interscapular brown adipose tissue (IBAT) and weights ( $\mathrm{g} / \mathrm{kg}$ carcass) of IBAT, kidney and epididymal fat pads of starting controls (T5), rats given diet $I$ ad lib. $(T 1)$, force-fed diet $2(T 2)$ or offered a varied diet in combination with diet $I(T 3)$ or diet 3 (T4) for $21 d \dagger$

(Mean values and standard error of the difference for six rats, $18 \mathrm{df}$ )

\begin{tabular}{lccccccc}
\hline \hline & & & & & & Statistical \\
Significance
\end{tabular}

${ }^{*} P<0.05, * * P<0.01,{ }^{* * *} P<0.001$.

$\dagger$ For details of diets and treatments, see Tables 1 and 2.

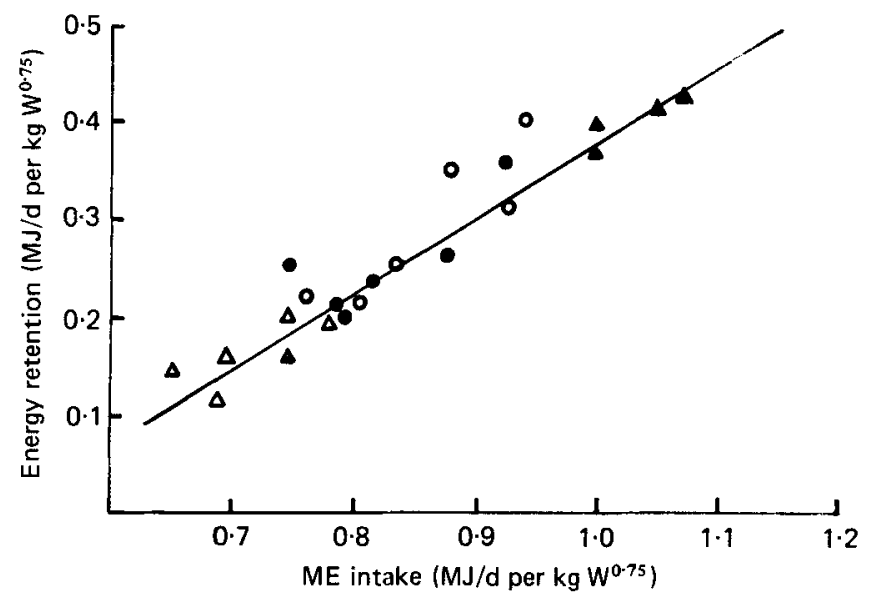

Fig. 1. Linear regression of energy retention ( $E R ; M J / d$ per $\mathrm{kg}$ body-weight $\mathrm{t}^{0.75}\left(\mathrm{~W}^{0 \cdot 75}\right)$ ) on $\mathrm{ME}$ intake (ME; MJ/d per $\mathrm{kg} \mathrm{W}^{0.75}$ ) for rats given diet 1 ad lib. $(\Delta)$, force-fed diet 2 (A) or offered a varied diet in combination with diet $1(O)$ or diet $3(O)$ for $21 \mathrm{~d}$. For details of diets and treatments, see Tables 1 and 2.

$$
\mathrm{ER}=0.78 \mathrm{ME}-395, \quad r 0.95
$$


Table 6. Weight (g) of liver, and dry matter (DM), crude protein (CP; nitrogen $\times 6 \cdot 25)$, fat and glycogen contents of liver $(g)$ of rats given diet 1 ad lib. (T1), force-fed diet $2(T 2)$ or offered a varied diet in combination with diet 1 (T3) or diet $3(T 4)$ for $21 d \dagger$

(Mean values and standard error of the difference for six rats, $13 \mathrm{df}$ )

\begin{tabular}{|c|c|c|c|c|c|c|}
\hline Treatment... & $\mathrm{T} 1$ & $\mathrm{~T} 2$ & T3 & $\mathrm{T} 4$ & SED & $\begin{array}{l}\text { Statistical } \\
\text { significance }\end{array}$ \\
\hline Liver wt (g) & 16.4 & $18 \cdot 5$ & $19 \cdot 0$ & $18 \cdot 3$ & $2 \cdot 21$ & NS \\
\hline $\mathrm{DM}$ (g/liver) & $4 \cdot 4$ & $7 \cdot 2$ & $5 \cdot 4$ & $5 \cdot 7$ & 0.90 & $* *$ \\
\hline $\mathrm{CP}(\mathrm{g} /$ liver) & $2 \cdot 9$ & $3 \cdot 2$ & $3 \cdot 0$ & $3 \cdot 2$ & $0 \cdot 33$ & NS \\
\hline Fat $(\mathrm{g} /$ liver $)$ & 0.5 & $3 \cdot 2$ & $1 \cdot 1$ & $1 \cdot 3$ & 0.86 & ** \\
\hline Glycogen ( $\mathrm{g} /$ liver) & $1 \cdot 0$ & 0.7 & $1 \cdot 1$ & 1.0 & 0.22 & NS \\
\hline
\end{tabular}

NS, not significant; ${ }^{* *} P<0.01$.

$\dagger$ For details of diets and treatments, see Tables 1 and 2.

The weight of the IBAT increased on all four treatments compared with the starting controls (Table 5). When expressed in proportion to carcass weight, there were no significant differences between $\mathrm{T} 1, \mathrm{~T} 3, \mathrm{~T} 4$ and $\mathrm{T} 5$ but the amount of IBAT of $\mathrm{T} 2$ rats was significantly higher $(P<0.05)$. Kidney and epididymal fat depots increased more rapidly than IBAT, and kidney more rapidly than epididymal fat. Within both depots, weight increased in the order $\mathrm{T} 5<\mathrm{T} 1<\mathrm{T} 4<\mathrm{T} 3<\mathrm{T} 2(P<0.001)$.

Liver weight (Table 6) was not significantly affected by treatment but liver DM was significantly higher in 'cafeteria'- and force-fed rats $(P<0.01)$ than in controls. The increased DM was almost entirely due to fat which increased in the order $\mathrm{T} 1<\mathrm{T} 3<\mathrm{T} 4<\mathrm{T} 2(P<0.01)$.

\section{DISCUSSION}

Although hyperphagia occurred in both groups offered a varied diet the extent of the response was somewhat less than had been expected from the reports of Rothwell \& Stock (1979). Consequently, the energy intake of the force-fed rats was higher than the mean values for T3 and T4 rats. The intake of stock diet by T3 and T4 rats was extremely low, approximately $10 \% \mathrm{ME}$ intake, and this had two consequences for the interpretation of the results. First, the fat content was higher, the values being 107,258 and $230 \mathrm{~g} / \mathrm{kg}$ respectively for diets $\mathrm{T} 2, \mathrm{~T} 3$ and $\mathrm{T} 4$ and the contents of calcium and phosphorus were lower in 'cafeteria' diets compared with the force-fed diet (Table 7). Also, the vitamin B content of the T3 diet was lower than that for T2. Second, the low stock intake resulted in the mean mineral and vitamin compositions of the total diet consumed by $\mathrm{T} 4$ rats being only slightly higher than that of the total diet consumed by T3 rats, and less than (US) National Research Council (1978) requirements. Thus the third objective of the experiment was not completely achieved. It is not clear whether the failure to observe any difference in energy utilization between T3 and T4 was due to the fact that both diets were deficient or that the deficiencies observed were not affecting the efficiency of energy utilization. The low Ca intakes of T3 and T4 rats are particularly disturbing and would have important implications in any long-term studies using a 'cafeteria'-feeding regimen.

The wide range of response of T3 and T4 rats to the varied diet is notable. Because of individual food preferences the proportion of fat $(\mathrm{g} / \mathrm{kg})$ in the total diet varied considerably (214-287 for T3 and 193-276 for T4 rats) and the extent of hyperphagia varied from 10 
Table 7. Nutrient intakes (per MJ metabolizable energy) of rats given diet 1 ad lib. (TI), force-fed diet $2(T 2)$ or offered a varied diet in combination with diet 1 (T3) or diet $3(T 4)$ for $21 d^{*}$ and the estimated requirements for growing rats ((US) National Research Council, 1978)

(Mean values for six rats)

\begin{tabular}{|c|c|c|c|c|c|}
\hline Treatment... & $\mathrm{T} 1$ & $\mathbf{T} 2$ & $\mathrm{~T} 3$ & $\mathrm{~T} 4$ & $\begin{array}{l}\text { (US) National Research } \\
\text { Council (1978) }\end{array}$ \\
\hline Crude protein (nitrogen $\times 6.25)(\mathrm{g})$ & $9.5+$ & $8 \cdot 8 \dagger$ & $9 \cdot 2$ & $9 \cdot 1$ & - \\
\hline Lysine $(\mathrm{g})$ & 1.06 & 0.95 & 0.61 & 0.61 & 0.44 \\
\hline Methionine/cystine (g) & 0.48 & 0.43 & $0 \cdot 35$ & $0 \cdot 35$ & 0.38 \\
\hline Calcium $(\mathrm{g})$ & $0.36 \dagger$ & $0.24 \dagger$ & 0.09 & $0 \cdot 10$ & 0.31 \\
\hline Phosphorus (g) & $0.43 \dagger$ & $0.30 \dagger$ & $0 \cdot 16$ & $0 \cdot 18$ & $0 \cdot 25$ \\
\hline Thiamin $(\mathrm{mg})$ & $0 \cdot 31$ & $0 \cdot 18$ & $0 \cdot 12$ & $0 \cdot 20$ & $0 \cdot 25$ \\
\hline Riboflavin (mg) & $0 \cdot 19$ & $0 \cdot 14$ & $0 \cdot 10$ & $0 \cdot 17$ & $0 \cdot 19$ \\
\hline Pyridoxine (mg) & $0 \cdot 31$ & $0 \cdot 18$ & $0 \cdot 10$ & $0 \cdot 18$ & $0 \cdot 38$ \\
\hline
\end{tabular}

* For details of diets and treatments, see Tables 1 and 2.

$\dagger$ Determined directly; all other values calculated from ingredients using food tables (Paul \& Southgate, 1978).

to $60 \%$ of the control value. Large differences in response have also been noted by Armitage et al. (1981) and are of interest in relation to possible hormonal or sensory factors affecting regulation of energy intake.

The differences in body composition which occurred are of interest for several reasons. First, it is clear that the 'cafeteria' regimen did not result in protein deficiency. It seems probable in fact that the $\mathrm{T} 3$ and $\mathrm{T} 4$ rats were achieving close to the maximum protein deposition rate. The calculated mean $\mathrm{CP}$ intakes $(\mathrm{g} / \mathrm{d})$ for $\mathrm{T} 1, \mathrm{~T} 2$, T3 and T4 were $3 \cdot 0,3 \cdot 7$, 3.7 and 3.4 respectively. The intakes $(\mathrm{g} / \mathrm{d})$ of lysine and methionine/cystine were $0.32,0.43$, 0.25 and 0.22 , and $0.15,0 \cdot 19,0 \cdot 15$ and 0.13 and the mean $\mathrm{CP}$ retentions $(\mathrm{g} / \mathrm{d})$ for $\mathrm{T} 1, \mathrm{~T} 2$, $\mathrm{T} 3$ and $\mathrm{T} 4$ were $1 \cdot 04,0 \cdot 65,1 \cdot 11$ and $1 \cdot 14$ respectively.

Second, the force-fed diet also supplied adequate amounts of protein and amino acids but $\mathrm{CP}$ retention was severely reduced. Similar effects in force-fed rats have been reported previously (Cohn \& Joseph, 1963; McCracken, 1975) but the mechanism has not been established. Another side-effect of force-feeding is the lipid accumulaton in the liver which has also been reported in previous experiments (Denton et al. 1950; Sidransky \& Baba, 1960). For these two reasons it is considered that force-feeding may not be a satisfactory means of achieving hyperphagia in young animals.

Third, there were large differences in fat content (and hence energy content) of the weight gain. Although the mean daily gain of T3 and T4 rats was only $45 \%$ higher than that of $\mathrm{T} 1$ rats, daily energy retention was increased $100 \%$. The effect was even greater with $\mathrm{T} 2$ rats where daily gain was increased by $25 \%$ and energy retention by $176 \%$. This emphasizes the dangers inherent in estimating energy retention from weight gain (see also McCracken \& McNiven, 1983).

Despite the differences in diet composition the efficiency of energy utilization was uniformly high. Because of the wide range of intakes achieved, it was considered acceptable to plot a linear regression of ER on ME intake. Statistical analysis confirmed that a single slope yielded as good a fit to the figures as individual slopes. The mean intercept for zero energy balance of $510 \mathrm{~kJ} / \mathrm{kg} \mathrm{W}^{0.75}$ is higher than that observed by McCracken \& McNiven (1983) with adult female rats, and higher than that obtained by regression by Pullar \& Webster (1977). If a lower value for maintenance heat production (e.g. $400 \mathrm{~kJ} / \mathrm{kg} \mathrm{W}^{0 \cdot 75}$ ) is applied to the individual treatments the partial efficiency of energy utilization $(k)$ for $T 1$, 
$\mathrm{T} 2, \mathrm{~T} 3$ and $\mathrm{T} 4$ respectively becomes $0.52,0.64,0.64$ and 0.59 , indicating a higher efficiency of utilization for 'careteria'-fed rats than for controls. The results are clearly in conflict with the reports of increased oxygen consumption (Andrews \& Donne, 1982) and with results obtained at $24^{\circ}$ by Rothwell \& Stock (1979). However, they are in agreement with those of Armitage et al. (1981) and Bestley et al. (1982).

The $k$ value determined by regression $(0 \cdot 78)$ is somewhat lower than that obtained by McCracken \& McNiven (1983) with adult rats (0.88). This is probably attributable to the higher energy cost of protein synthesis (Pullar \& Webster, 1977) compared with the relatively low cost of direct fat incorporation in the adult rat.

The difference in response to 'cafeteria'-feeding observed in the present experiment and that reported by Rothwell \& Stock (1979) is not easy to explain. Hervey \& Tobin (1982a) have already drawn attention to some of the errors which arose in the Rothwell \& Stock (1979) experiment. However, one has to assume large errors in estimation of the energy intake of the 'cafeteria'-fed animals in addition to the obvious error in the calculated intake of the controls. It is unlikely that the difference in environmental temperature will provide an explanation.

IBAT has been implicated in cold-induced thermogenesis (Foster \& Frydman, 1978) in the rat and a similar role in so-called 'diet'-induced thermogenesis has been suggested (Rothwell \& Stock, 1979; Tulp et al. 1982). The present results show that large increases in IBAT weight result from force-feeding or from offering a varied diet without any increase in heat production. The appearance of the IBAT of T3, T4 and, more especially, T2 rats was paler than that of $\mathrm{T} 1$ rats and this was probably due to increased deposition of triglyceride. This conclusion is in agreement with the results of Hervey \& Tobin (1982b). The weight increases of the kidney and epididymal fat depots in force-fed and 'cafeteria'-fed rats were relatively larger than in IBAT. In the 'cafeteria'-fed rats these two depots accounted for approximately $30 \%$ of the extra fat stored.

It is clear that further studies are required to elucidate the cause of the large differences in response obtained in different laboratories. The present results are consistent with results obtained in rats made hyperphagic by other methods (McCracken \& McNiven, 1983) and with the known effects of high-fat diets on the efficiency of energy utilization in other mammals (Vanschoubroek, 1966; Boyd, 1978). It seems probable, therefore, that the results of Rothwell \& Stock (1979), Andrews \& Donne (1982) and Trayhurn et al. (1982) arise from one or more experimental artefacts and are unlikely to be of relevance to the study of human obesity or to the efficiency of energy utilization of farm animals.

H.G. B. acknowledges the award of a post-graduate research studentship by the Department of Agriculture, Northern Ireland.

\section{REFERENCES}

Agricultural Research Council (1981). The Nutrient Requirements of Pigs. Slough: Commonwealth Agricultural Bureaux.

Andrews, J. F. \& Donne, B. (1982). Proceedings of the Nutrition Society 41, 36A.

Armitage, G., Hervey, G. R., Rolls, B. J., Rowe, E. A. \& Tobin, G. (1981). Journal of Physiology 317, 48P.

Bestley, J. W., Bramley, P. N., Dobson, P. M. S., Mahanty, A. \& Tobin, G. (1982). Journal of Physiology 330, 70 P.

Boyd, J. (1978). Drug and dietary manipulation of fat and protein deposition in the growing rat and pig. PhD

Thesis, The Queen's University of Belfast.

Brouwer, E. (1965). European Association for Animal Production, Publication No. 11, 441-443.

Cohn, C. \& Joseph, D. (1959). American Journal of Physiology 196, 965-968.

Cohn, C. \& Joseph, D. (1963). American Journal of Physiology 205, 71-78.

Denton, A. E., Williams, J. N. \& Elvehjem, C. A. (1950). Journal of Nutrition 42, 423-432.

Foster, D. O. \& Frydman, M. L. (1978). Canadian Journal of Physiology and Pharmacology 56, $110-122$.

Hervey, G. R. \& Tobin, G. (1982a). Proceedings of the Nutrition Society 41, 137-154.

Hervey, G. R. \& Tobin, G. (1982b). Journal of Physiology 330, 71 P. 
McCracken, K. J. (1975). British Journal of Nutrition 33, 277-289.

McCracken, K. J. \& Gray, R. (1976). European Association of Animal Production, Publication No. 19, 141-144.

McCracken, K. J. \& McNiven, M. A. (1983). British Journal of Nutrition 49, 193-202.

Mickelsen, O., Takahashi, S. \& Craig, C. (1955). Journal of Nutrition 57, 541-554.

National Research Council (1978). Nutrient Requirements of Laboratory Animals, 3rd revised ed. Washington DC: National Academy of Sciences.

Paul, A. A. \& Southgate, D. A. T. (1978). McCance and Widdowsons ' The Composition of Foods', 4th ed. London: H.M. Stationery Office.

Pullar, J. D. \& Webster, A. J. F. (1977). British Journal of Nutrition 37, 355-363.

Rothwell, N. J. \& Stock, M. J. (1979). Nature 281, 31-35.

Rothwell, N. J. \& Stock, M. J. (1982). Journal of Nutrition 112, 1515-1524.

Scalafani, A. \& Springer, D. (1976). Physiology and Behaviour 17, 461-471.

Schemmel, R., Mickelsen, O. \& Motani, K. (1972). Journal of Nutrition 102, 1187-1 197.

Sidransky, H. \& Baba, T. (1960). Journal of Nutrition 70, 463-483.

Swift, R. W. (1944). Journal of Nutrition 28, 359-364.

Trayhurn, P., Jones, P. M., McGuckin, M. M. \& Goodbody, A. E. (1982). Nature 295, 323-325.

Tulp, O. L., Frink, R. \& Danforth, E. (1982). Life Sciences 30, 1525-1530.

Vanschoubroek, F. X. (1966). World Congress on Animal Feeding, Madrid 1, 217-262. 